\title{
Numerical modeling of the impact of sea-level rise on fringing coral reef hydrodynamics and sediment transport
}

\author{
C. D. Storlazzi $\cdot$ E. Elias $・$ M. E. Field • \\ M. K. Presto
}

Received: 7 September 2010/Accepted: 7 January 2011/Published online: 25 January 2011

(C) The Author(s) 2011. This article is published with open access at Springerlink.com

\begin{abstract}
Most climate projections suggest that sea level may rise on the order of $0.5-1.0 \mathrm{~m}$ by 2100 ; it is not clear, however, how fluid flow and sediment dynamics on exposed fringing reefs might change in response to this rapid sea-level rise. Coupled hydrodynamic and sedimenttransport numerical modeling is consistent with recent published results that suggest that an increase in water depth on the order of $0.5-1.0 \mathrm{~m}$ on a 1-2 $\mathrm{m}$ deep exposed fringing reef flat would result in larger significant wave heights and setup, further elevating water depths on the reef flat. Larger waves would generate higher near-bed shear stresses, which, in turn, would result in an increase in both the size and the quantity of sediment that can be resuspended from the seabed or eroded from adjacent coastal plain deposits. Greater wave- and wind-driven currents would develop with increasing water depth, increasing the alongshore and offshore flux of water and sediment from the inner reef flat to the outer reef flat and fore reef where coral growth is typically greatest. Sediment residence time on the fringing reef flat was modeled to decrease exponentially with increasing sea-level rise as the magnitude of sea-level rise approached the mean water depth over the reef flat. The model results presented here
\end{abstract}

Communicated by Guest Editor Dr. Clifford Hearn

C. D. Storlazzi $(\bowtie) \cdot$ M. E. Field · M. K. Presto

US Geological Survey, Pacific Coastal and Marine Science Center, 400 Natural Bridges Drive, Santa Cruz, CA 95060, USA

e-mail: cstorlazzi@usgs.gov

E. Elias

US Geological Survey/Deltares, 345 Middlefield Road, MS-999,

Menlo Park, CA 94025, USA suggest that a $0.5-1.0 \mathrm{~m}$ rise in sea level will likely increase coastal erosion, mixing and circulation, the amount of sediment resuspended, and the duration of high turbidity on exposed reef flats, resulting in decreased light availability for photosynthesis, increased sediment-induced stress on the reef ecosystem, and potentially affecting a number of other ecological processes.

Keywords Sea level - Fringing reef - Waves - Currents . Sediment $\cdot$ Erosion

\section{Introduction}

While rising sea-surface temperatures and ocean acidification have received most of the attention regarding the impacts of climate change on coral reefs, the impact to coral reefs from predicted future rising sea level has only been addressed by a few researchers (Graus and Macintyre 1998; Ogston and Field 2010). A number of recent studies (Grinsted et al. 2009; Merrifield et al. 2009) point out that not only is global sea level rising, but the rate is increasing in response to global climate change. Syntheses by Grinsted et al. (2009) and Nicholls and Cazenave (2010) suggest that global mean sea level in 2100 may exceed the 2000 level by two to three times the average IPCC (2007) projection of approximately $60 \mathrm{~cm}$ above 2000 levels. Since corals' upward growth is constrained by exposure to air at low tides, Buddemeier and Smith (1988) and Edwards (1995) suggested that coral reef flats may benefit from the additional accommodation space, as detrimental exposure to air would decrease with sea-level rise. Buddemeier and Smith (1988), however, qualify this conclusion as long as “... [coral] communities are protected from destructive waves and not subjected to heavy sedimentation...". 
Increased turbidity over coral reefs due to suspended sediment can decrease light available for photosynthesis (Marszalek 1981; Phillip and Fabricius 2003; Piniak and Storlazzi 2008) and modify coral reef zonation by affecting coral fertilization and recruitment, which, in turn, can result in stress to or mortality of corals (e.g., Rogers 1990; Phillip and Fabricius 2003; Fabricius 2005). Recently, a number of studies have addressed the growing problem of coral reefs impacted by anthropogenic modification of coastal watersheds (e.g., Wolanski et al. 2003; Field et al. 2008), acknowledging that climate change may alter the quantity and timing of sediment delivery to coral reefs.

Despite the widespread discussion of climate change impacts on reefs, there has been little discussion of how sea-level rise may affect fringing coral reefs, in terms of both hydrodynamics and sediment dynamics. A number of studies of bio-physical coupling on reefs (e.g., Sebens and Johnson 1991; Edwards 1995; Falter et al. 2004; Storlazzi et al. 2005) have shown that hydrodynamics control many ecological aspects of reef systems, including photosynthesis, nutrient uptake, prey capture, coral bleaching, and species distribution. Ogston and Field (2010) presented one-dimensional model results from Molokai, Hawaii, USA, demonstrating that twenty-first-century sea-level rise will increase wave heights and suspended-sediment concentrations and cause longer periods of elevated turbidity on the coral reef flat.

In this paper, a two-dimensional numerical profile model of hydrodynamics and sediment transport over the Molokai fringing reef was calibrated with in situ data and was driven by meteorologic and oceanographic forcing conditions that characterize most exposed (not sheltered) tropical coral reefs. The goal of this effort is to better understand the relative importance of different processes (e.g., winds and waves) to hydrodynamics and sediment transport, and the contribution of these different characteristic sets of forcing conditions to annual sediment fluxes. Model results for various projections of sea-level rise are presented to identify the relative importance of these different forcing conditions to hydrodynamics and sediment transport in different sealevel rise scenarios. Reef accretion or changes in roughness were not modeled in these sea-level rise scenarios because published vertical reef flat accretion rates for exposed fringing reefs (1-4 mm year ${ }^{-1}$ per Buddemeier and Smith 1988; Montaggioni 2005) are up to an order of magnitude smaller than the rates of sea-level rise projected for the years 2000-2100 (8-16 $\mathrm{mm}_{\text {year }}{ }^{-1}$ per Grinsted et al. 2009; Nicholls and Cazenave 2010). These data suggest that projected sea-level rise will outstrip potential new reef flat accretion, resulting in a net increase in water depth over exposed fringing reef flats on the order of 0.4-1.5 m during the twenty-first century. Lastly, the implications of these results in the health and sustainability for fringing coral reefs under projected sea-level rise are discussed.

\section{Study area}

The data presented here are from Molokai, Hawaii, in the north-central Pacific Ocean $\left(\sim 21^{\circ} \mathrm{N}, 157^{\circ} \mathrm{W}\right)$ between the islands of Oahu and Maui. The physical environment in the Hawaiian Islands during the summer is dominated by $5-10 \mathrm{~m} \mathrm{~s}^{-1}$ northeasterly trade winds that generate wave heights of 1-3 $\mathrm{m}$ with periods of 5-8 $\mathrm{s}$ and small (1-2 m), long-period (14-25 s) south swells (Moberly and Chamberlain 1964). Winter conditions, typically beginning in October and extending through March, are characterized by storms and North Pacific swell that produce wave heights of 3-6 $\mathrm{m}$ with periods of 10-18 s that approach from the northwest. Due to shadowing by the surrounding islands and the island of Molokai itself, however, most of south Molokai's fringing reef is sheltered from large North Pacific swell but is exposed to the other wave climates. Hawaii has a mixed, semidiurnal microtidal regime, with the mean daily tidal range of approximately $0.6 \mathrm{~m}$ and the minimum and maximum daily tidal ranges are 0.4 and $0.9 \mathrm{~m}$, respectively (Ogston et al. 2004; Storlazzi et al. 2004).

The morphology of the south Molokai fringing reef is discussed in detail by Storlazzi et al. (2003) and is summarized here. The reef flat, a roughly horizontal surface with water depths ranging from 0.3 to $2.0 \mathrm{~m}$, extends seaward from the shoreline for distances from 0.5 to $1.5 \mathrm{~km}$ offshore. Calcareous marine sediment dominates the coarse-grained fraction of the bed sediment (58-65\%; Field et al. 2008) across the entire fringing reef tract. The inner portion of the reef flat is covered by a wedge of muddy sand (80-90\% of the silt and finer grain sizes are terrigenous in origin) that pinches out roughly $200-300 \mathrm{~m}$ offshore (Fig. 1a). From this point out to roughly $500 \mathrm{~m}$ offshore, an ancestral reefal hardground is intermittently exposed or mantled by sediment and algae. Shore-normal ridge-and-runnel structure characterizes the reef flat from $500 \mathrm{~m}$ out to the reef crest roughly $1,000 \mathrm{~m}$ offshore. The coral ridges are covered by low percentages of live coral, and the runnel depressions are filled by calcareous sediment. The reef crest, where most deepwater waves break, is generally well defined along many of the fringing reefs in Hawaii and is locally covered by encrusting coralline algae and robust lobate and encrusting corals. Offshore of the reef crest, from depths of 3-30 m, lies the fore reef that is generally characterized by 1-3 $\mathrm{m}$ high shore-normal spurand-groove structures covered by discontinuous, highly variable percentages of live coral (Jokiel et al. 2001). 


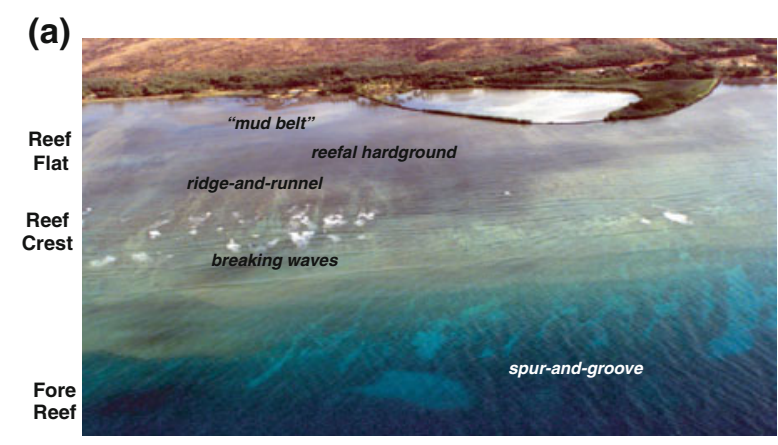

(b)

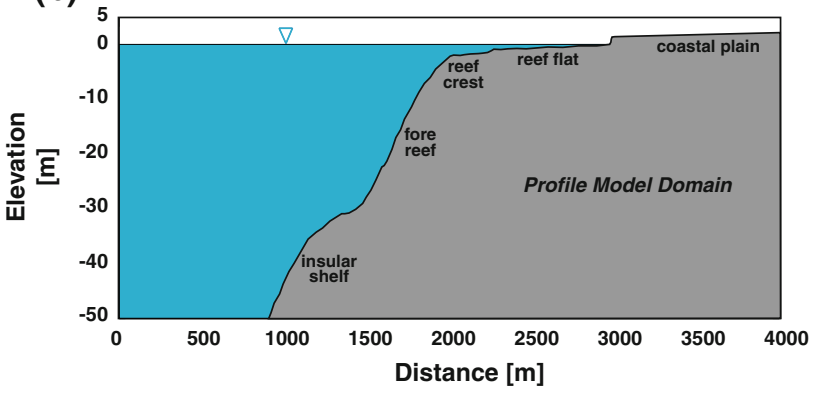

(c)

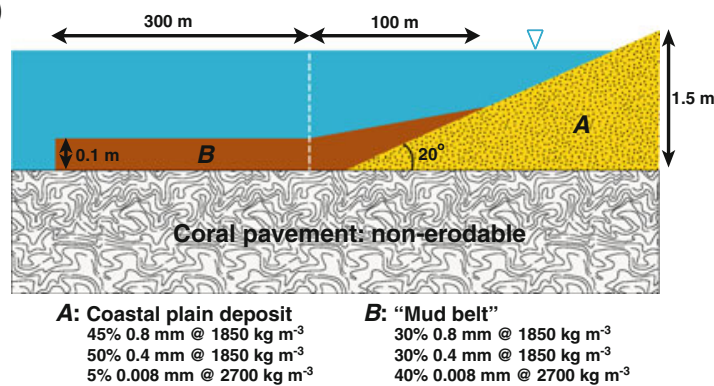

Fig. 1 The bathymetry, dominant zones, and geologic features of a fringing coral reef. a Oblique aerial photograph of the south Molokai, Hawaii, fringing coral reef. b Bathymetry and topography used in the numerical model. c The morphology and sedimentology of the inner reef flat, "mud belt", and coastal plain deposit in the numerical model

\section{Methods}

\section{Field observations}

The in situ observations used for model calibration and validation were presented by Storlazzi et al. (2004) and Presto et al. (2006) and are summarized here. Current velocity data were collected via acoustic Doppler current profilers, acoustic Doppler velocimeters, or single-point electromagnetic current meters. Data loggers collected and stored data from these instruments as well as pressure to provide information on tides and waves. Optical backscatter sensors and the acoustic backscatter from acoustic Doppler current profilers and acoustic Doppler velocimeters provided information on turbidity and suspendedsediment concentrations. These instruments were mounted on tripods or deployed from a mobile "backpack" in water depths ranging from 0.5 to $11.0 \mathrm{~m}$.

\section{Numerical modeling}

The Delft3D Online Morphology system (Lesser et al. 2004; Delft User Manual 2010) was used to model hydrodynamics and sediment transport over the south Molokai fringing coral reef. The main components are the two-way coupled Delft3D SWAN and FLOW modules modeling waves and currents, respectively. FLOW forms the core of the model system, simulating water motion due to tidal and meteorological forcing by solving the unsteady shallow-water equations that consist of the continuity equation, the horizontal momentum equations, and the transport equation under the shallow water and Boussinesq assumptions. Wave effects, such as enhanced bed shear stresses and radiation stresses, are included in the flow simulation by coupling the FLOW module with stationary runs of the third-generation SWAN wave model (Walstra et al. 2000). SWAN is based on discrete spectral action balance equations, computing the evolution of random, short-crested waves (Holthuijsen et al. 1993; Booij et al. 1999; Ris et al. 1999). Physical processes included are the generation of waves by wind, nonlinear quadruplet and triad wave-wave interactions, and dissipation due to whitecapping, bottom friction, and depth-induced breaking.

The Delft3D Online Morphology model was used to resolve the sediment resuspension and transport dynamically. At each computational time-step, Online Morphology supplements the FLOW module results with sediment transport using the Van Rijn (1993) formulation, wherein a distinction is made between bed-load and suspended-load transport. Bed-load transport represents the transport of sand particles in the wave boundary layer close to the seabed. Suspended-sediment transport is computed by the advection-diffusion solver. To describe sediment characteristics, additional formulations are included to account for density effects of sediment in suspension, settling velocity, vertical diffusion coefficient for sediment, suspended-sediment correction vector, and sediment exchange with the bed. The elevation of the bed is dynamically updated at each computational time-step by calculating the change in mass of the bottom sediment resulting from the gradients in sediment transport.

The bed was schematized in three non-cohesive sediment classes (Fig. 1c) to represent the sediment observed on the reef flat off south Molokai (Field et al. 2008). For the fine terrigenous sediment (fine silt), a mean grain size $\left(d_{50}\right)$ of $0.008 \mathrm{~mm}$ and a density of $2,700 \mathrm{~kg} \mathrm{~m}^{-3}$ was prescribed, medium-sized carbonate sediment (fine sand) was characterized by $d_{50}=0.2 \mathrm{~mm}$ and density of $1,850 \mathrm{~kg} \mathrm{~m}^{-3}$, and coarse carbonate sediment (medium 
sand) with $d_{50}=0.4 \mathrm{~mm}$ and density of $1,850 \mathrm{~kg} \mathrm{~m}^{-3}$. In the model, sediment was initially present only in a narrow band extending $400 \mathrm{~m}$ from the shoreline while the remainder of the model was initially a non-erodible layer that represented the coral pavement of the fringing reef flat (thin, discontinuous sediment deposits were discounted) based on field observations. The total amount of sediment available in the profile was $56.7 \mathrm{~m}^{3}$ of fine sediment, $18.2 \mathrm{~m}^{3}$ of which is contained in the mud belt ("B"), $27.9 \mathrm{~m}^{3}$ of medium sediment, and $784 \mathrm{~m}^{3}$ of coarse sediment contained in the coastal plain deposit ("A"). The volumes in the coastal plain deposit were somewhat arbitrary, as these depended on the landward extent of the model. The model did allow for sediment accumulation and subsequent erosion of accumulated sediment on the coral pavement during the sediment-transport simulations. Sediment fractions are solved individually in the transport and bed-update modules and therefore were tracked separately. Hydraulic roughness length scales were varied between approximately 0.01 and $0.10 \mathrm{~m}$, with the higher value used for coral surfaces based on previous observations on Hawaiian reefs and numerical modeling results (e.g., Hearn 1999; Lowe et al. 2005), and the lower range $(\sim 0.01 \mathrm{~m})$ set by the seabed grain size. Complete overviews of the formulations, testing, and validation of Delft3D Online Morphology have been reported in Lesser et al. (2004). See Walstra and Van Rijn (2003), and Van Rijn (1993, 2007a, b, c) for the specific transport formulations.

Because most fringing reefs are relatively uniform alongshore in water depth and hydrodynamic roughness at larger scales (order $\sim 100 \mathrm{~s}$ of $\mathrm{m}$ ) but heterogeneous at smaller scales (order $\sim \mathrm{m}$ ) due to ridge-and-runnel structures on the reef flat and spur-and-groove structures on the fore reef, a fully realistic three-dimensional model at the spatial scales necessary to resolve the heterogeneity would be too computationally intensive. For this reason, a schematized two-dimensional profile model was used to acquire insight into the dominant sediment-transport processes across a fringing coral reef. Since the model is only one grid cell in the alongshore direction, high vertical and cross-shore resolution could be obtained while minimizing computational time. An underlying assumption in this approach is the dominance of wind- and wave-driven processes. This assumption is justified based on the small tidal velocities observed in the study area (Ogston et al. 2004; Storlazzi et al. 2004; Presto et al. 2006). Model validation therefore was focused on accurate representation of the wave-breaking processes. Sensitivity analyses were performed on variations in the forcing by varying the seasonally schematized input conditions, profile dimensions, and the mean water level, including sea-level rise scenarios. The model bathymetry was based on averaging a number of cross-shore profiles from the high-resolution
SHOALS lidar data presented by Storlazzi et al. (2003). The model grid had a $10-\mathrm{m}$ cross-shore resolution, resulting in a total of 350 grid cells in the cross-shore direction for each vertical layer (Fig. 1b). The model was schematized in the vertical by 8 sigma layers with a thickness of 2 , $3,5,8,12,20,25$, and $25 \%$ of the total water depth from the seabed up to the surface.

High-resolution in situ measurements of tides, waves, currents, and suspended-sediment concentrations across the central part of the Molokai fringing reef were available only for a 40-d time frame (Storlazzi et al. 2004). These temporally limited in situ measurements were used for model calibration and validation; however, they may not be representative for the conditions that govern sediment transport over a range of seasons. To enable sedimenttransport simulations for periods of time longer than the duration of instrument measurements, schematized forcing conditions for tides, wind, and waves were used. The technique described by Lesser et al. (2004) was applied to the water-level data from Presto et al. (2006) in order to generate a morphodynamic schematized tide to force the open ocean boundary (Table 1). The objective of the tidal schematization (input reduction) is to replace the full tide that is composed of all constituents that represent the full spring/neap cycle with a simplified 24.8-h tidal cycle that closely matches the residual tidally driven transport of the full lunar monthly tidal cycle. Such simplified tide should reproduce the residual sediment-transport rates and resulting morphological change over the period of interest in the entire model domain.

The second important schematization was that of the wind and wave climate. The schematization used in this effort was based on the analysis of meteorologic and oceanographic data for the region (Presto et al. 2006; Storlazzi and Jaffe 2008) but is characteristic of most exposed coral reefs worldwide (e.g., Spalding et al. 2001; Riegl and Dodge 2008). This schematization resulted in four classes of distinct forcing conditions (Table 2). The Trade Wind conditions are the most prevalent, occurring $62 \%$ of the time during a year (226 days year $\left.{ }^{-1}\right)$. During Trade Wind conditions, the wind is relatively strong and wave heights are moderate. Events characterized by minor wind and wave energy are schematized by the Variable

Table 1 Tidal constituents of the simplified tide used to force the open ocean model boundary based on the application of the Lesser et al. (2004) methodology

\begin{tabular}{llc}
\hline Constituent & $\begin{array}{l}\text { Amplitude } \\
(\mathrm{m})\end{array}$ & $\begin{array}{l}\text { Phase } \\
\left({ }^{\circ}\right)\end{array}$ \\
\hline $\mathrm{AO}$ & 0.780 & - \\
$\mathrm{M} 2$ & 0.178 & 64.7 \\
$\mathrm{C} 1$ & 0.131 & 75.15 \\
\hline
\end{tabular}


group, which occurs $25 \%$ of the time $\left(91\right.$ days year $^{-1}$ ). High-energy Swell (large, long-period waves with weak winds) and Storm conditions (large waves and strong winds) occur less frequently (10\% [37 days year $\left.{ }^{-1}\right]$ and $3 \%$ [11 days year ${ }^{-1}$ ], respectively). The model was then run for a year's time driven by the four sets of wind and wave forcing conditions for their respective durations (Trade Wind for 226 days, Storm for 11 days, etc.).

\section{Results}

Model calibration and validation

Calibration and validation of the numerical model focused on the water levels and wave heights. While the small tidal velocities were of minor importance in these simulations, the tidal water levels needed to be represented accurately. Root-mean-squared (RMS) errors between measured and modeled water levels across the reef (Fig. 2a-c) were $0.014 \mathrm{~m}$, and the RMS errors in wave height across the reef were $0.017 \mathrm{~m}$ (Fig. 2d-f), showing very good correspondence between the model and in situ data (Storlazzi et al. 2004). The modeled mean current speeds $\left(7.8 \mathrm{~cm} \mathrm{~s}^{-1}\right)$ on the reef flat slightly exceeded the observed values of $5.3 \pm 3.7 \mathrm{~cm} \mathrm{~s}^{-1}$ (mean $\pm \mathrm{SD}$; not shown); the modeled mean current speed on the fore reef $\left(5.0 \mathrm{~cm} \mathrm{~s}^{-1}\right)$ corresponded well to the observations $\left(4.1 \pm 4.9 \mathrm{~cm} \mathrm{~s}^{-1}\right)$. Importantly, the modeled tidal and total (wind + wave + tide $)$ current speeds were on the same order $(0-5$ and $5-20 \mathrm{~cm} \mathrm{~s}^{-1}$, respectively) as the measured currents and also showed the same proportion of greater $(\sim 2-8$ times) alongshore current speeds on the reef flat and over the fore reef compared to the cross-shore current speeds. This is in contrast, however, to most observations and models of primarily cross-shore flow and sediment transport on atolls and barrier reefs (e.g., Hearn 1999; Hearn and Atkinson 2000; Lowe et al. 2005) where vigorous wave-driven onshore flow over the reef flat can occur because it is balanced by strong return flow out of channels in the reef. In fringing reefs without a nearshore gully, wave-driven setup along the shoreline offsets this cross-reef flow and results in primarily alongshore flow and transport.
Contributions of waves and currents to sediment transport

With confidence that the numerical model was successfully reproducing the hydrodynamics on the reef flat and fore reef, the four schematized forcing conditions and the resulting sediment dynamics were modeled. The goal of these sediment dynamics simulations was not to reproduce reality, for the schematized model domain and duration of forcing conditions when compared to the limited in situ measurements made this not possible. Rather, the goal was to understand the relative contribution of the different forcing mechanisms to flow and sediment transport and how these contributions would vary with sea-level rise. The mean forcing and resulting suspended-sediment concentrations for the four schematized forcing conditions are shown in Fig. 3; the resulting sediment transport for a 1-year simulation comprised of the four schematized forcing conditions is shown in Fig. 4. Overall, sediment transport was dominated by the fine-grained fractions. No coarse- or medium-grained fractions were moved on the reef flat during the base (sea level $=0.00 \mathrm{~m}$ ) simulations. The bulk of the wave energy was dissipated along the reef crest, and the depth-averaged current speeds in the "mud belt" were small and did not exceed the critical threshold of motion for the larger (medium and coarse sand) grainsize fractions, resulting in a narrow band of elevated finegrained sediment concentrations along the shoreline. No significant sediment losses to deep water were encountered as a result of the minor water level gradient-induced offshore flow near the bed, resulting in most of the sediment transport laterally alongshore in a band extending from the shoreline seaward approximately $400 \mathrm{~m}$, which matches observations (Presto et al. 2006; Field et al. 2008).

The model results show distinctively different transport rates during the different forcing conditions. Storm conditions dominated the hydrodynamics and resulting sediment dynamics despite their low frequency of occurrence. Storm conditions generated the greatest setup on the reef flat (Fig. 3b) due to the strong winds and highest wave energy on the fore reef (Fig. 3c). The winds and waves drove strong $\left(\sim 5-15 \mathrm{~cm} \mathrm{~s}^{-1}\right)$ currents across the fore reef and reef flat (Fig. 3d) and, together, generated high shear

Table 2 Model schematization of wind and wave conditions. In the model, the coast trends north-south $\left(0-180^{\circ}\right)$, with eastward $\left(90^{\circ}\right)$ being oriented onshore

\begin{tabular}{|c|c|c|c|c|c|c|}
\hline Climate & $\begin{array}{l}\text { Percent of } \\
\text { days year }\end{array}$ & $\begin{array}{l}\text { Wind direction } \\
\left({ }^{\circ}\right)\end{array}$ & $\begin{array}{l}\text { Wind speed } \\
\left(\mathrm{m} \mathrm{s}^{-1}\right)\end{array}$ & $\begin{array}{l}\text { Wave height } \\
\text { (m) }\end{array}$ & $\begin{array}{l}\text { Wave period } \\
\text { (s) }\end{array}$ & $\begin{array}{l}\text { Wave direction } \\
\left({ }^{\circ}\right)\end{array}$ \\
\hline Trade Wind & 62 & 190 & 10 & 1 & 6 & 190 \\
\hline Variable & 25 & 80 & 3 & 0.5 & 6 & 240 \\
\hline Swell & 10 & 170 & 3 & 1 & 14 & 280 \\
\hline Storm & 3 & 280 & 20 & 1.5 & 8 & 280 \\
\hline
\end{tabular}


(a)

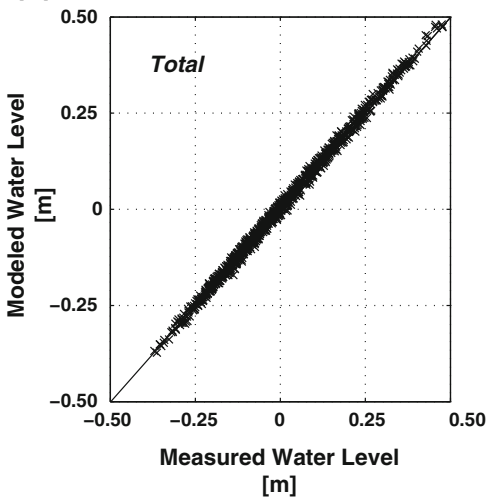

(d)

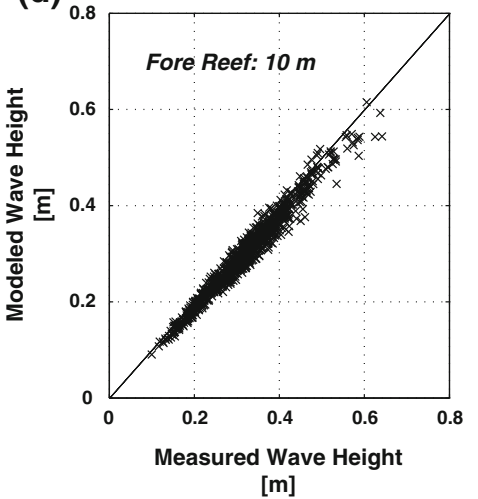

(b)

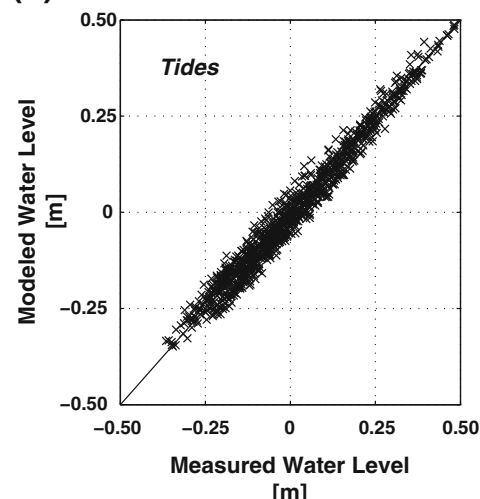

(e)

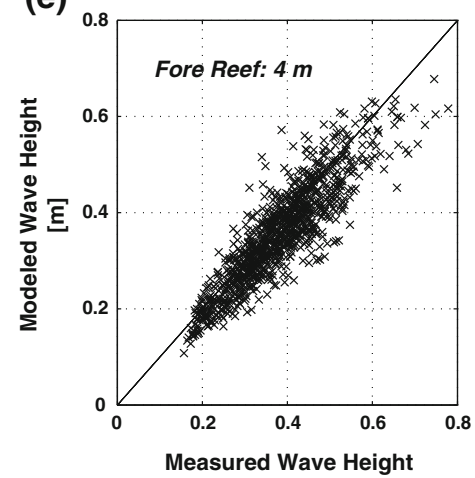

$[\mathrm{m}]$ (c)

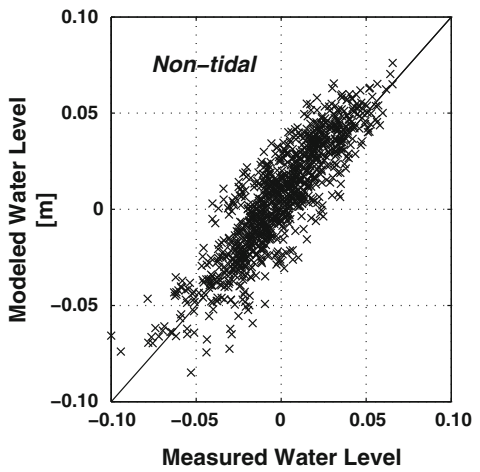

[m]

(f)

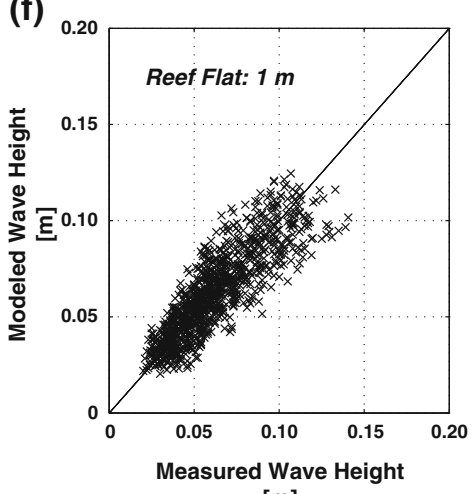

[m]
Fig. 2 Comparison of in situ measurements (Storlazzi et al. 2004) and model results of water levels and wave heights. a Total water level on the reef flat (depth $\sim 1 \mathrm{~m}$ ). b The tidal component of water level on the reef flat. $\mathbf{c}$ The non-tidal component of water level on the

stresses that resuspended large quantities of sediment across the inner reef flat (Fig. 3e). Even though the Swell conditions did not generate strong currents, the long period of the waves generated substantial long-wave energy that caused almost $5 \mathrm{~cm}$ of setup. These long-wave motions during the Swell conditions resulted in higher peak suspended-sediment concentrations right at the shoreline than modeled during the Storm conditions, but this zone of elevated suspended-sediment concentrations was confined closer to shore and thus a lower total mass of sediment in suspension over the reef flat than in the Storm conditions. The Trade Wind conditions generated relatively strong wind-driven currents with little wave forcing and resulted in elevated suspended-sediment concentrations close to the shoreline, but these concentrations were on the order of a third to a quarter of those modeled during Storm and Swell conditions. Lastly, Variable conditions generated relative weak currents across the reef flat that resulted in suspended-sediment concentrations on the order of a third to a quarter of those modeled during Trade Wind conditions and almost an order of magnitude lower than during Storm and Swell conditions. Importantly, the waves, current reef flat. d Wave height on the fore reef (depth $\sim 10 \mathrm{~m}$ ). e Wave height on the fore reef (depth $\sim 4 \mathrm{~m}$ ). f Wave height on the reef flat (depth $\sim 1 \mathrm{~m}$ ). These comparisons show that the errors between observed and modeled water levels and wave heights are less than 5\%

speeds, and resulting suspended-sediment concentrations during the modeled forcing conditions match well with the in situ data collected under similar atmospheric and oceanographic forcing (Ogston et al. 2004; Storlazzi et al. 2004; Presto et al. 2006).

The relative contribution of the different sets of forcing conditions to annual sediment flux (Fig. 4) shows that Storm conditions are the dominant contributor to annual sediment flux, contributing just over twice the sediment flux that was modeled during Trade Wind conditions but in only $5 \%$ of the time (Fig. 4c; Table 3 ). This high percentage $(63 \%)$ of total annual sediment flux in only $11 \mathrm{~d}$ shows the importance of not only large waves and strong winds generating strong currents and high shear stresses, but the importance of setup increasing water depth over the reef flat that, in turn, allows for larger waves and stronger currents by reducing the hydrodynamic roughness relative to the depth of the water column. While Swell conditions resulted in high suspended-sediment concentrations at the shoreline (Fig. 3e), the greater cross-shore extent of elevated turbidity during Trade Wind conditions and their more frequent occurrence resulted in just under an order of 
Fig. 3 Modeled cross-shore variations in hydrodynamics and sediment dynamics for the four forcing conditions. a Morphology of the model domain. b Water level. c Shortwave energy. d Depth-averaged current speeds, with alongshore currents as solid lines and crossshore currents as dashed lines. e Suspended-sediment concentrations. While Swell conditions result in the highest wave energy and suspendedsediment concentrations on the reef flat, the greatest volume of suspended sediment over the reef flat results from Storm conditions

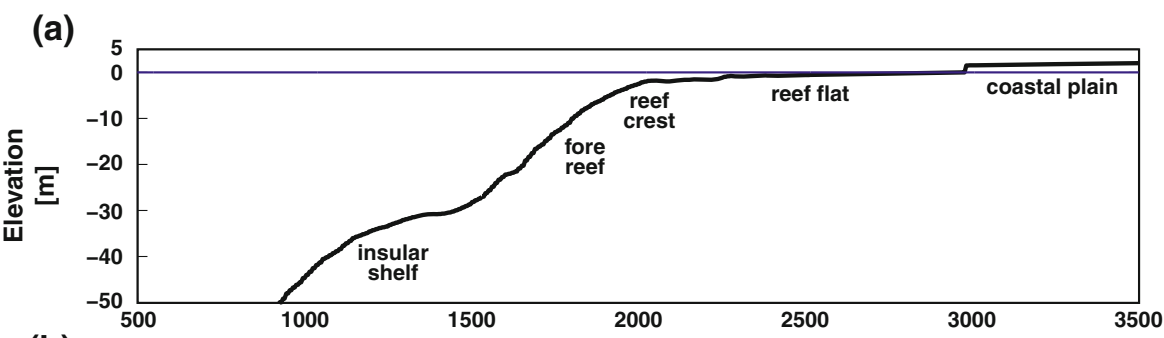

(b)

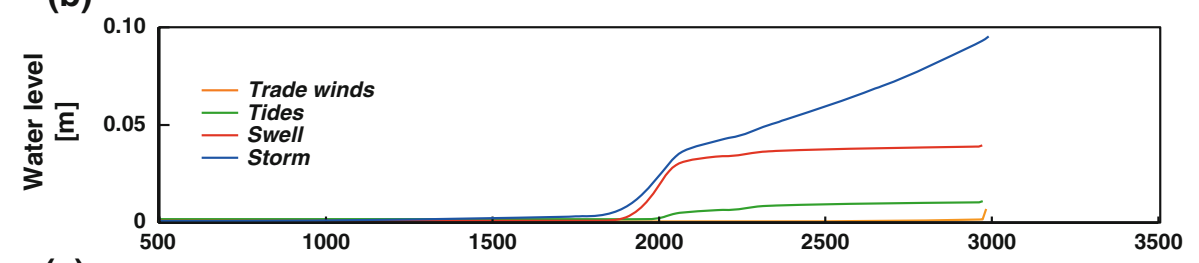

(c)

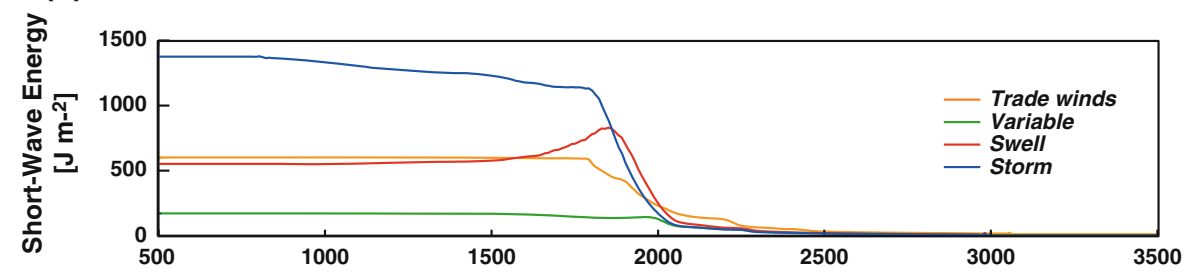

(d)

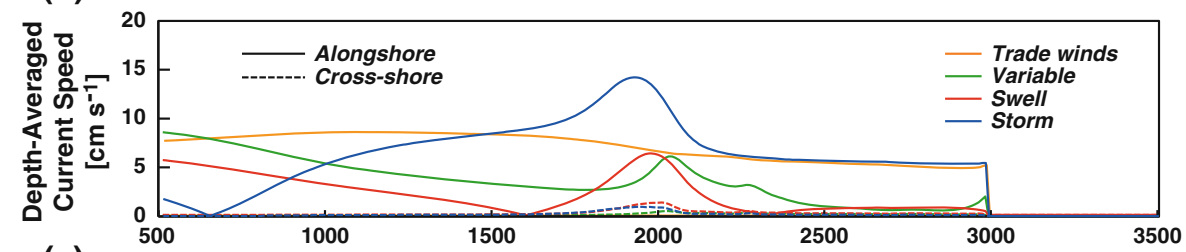

(e)

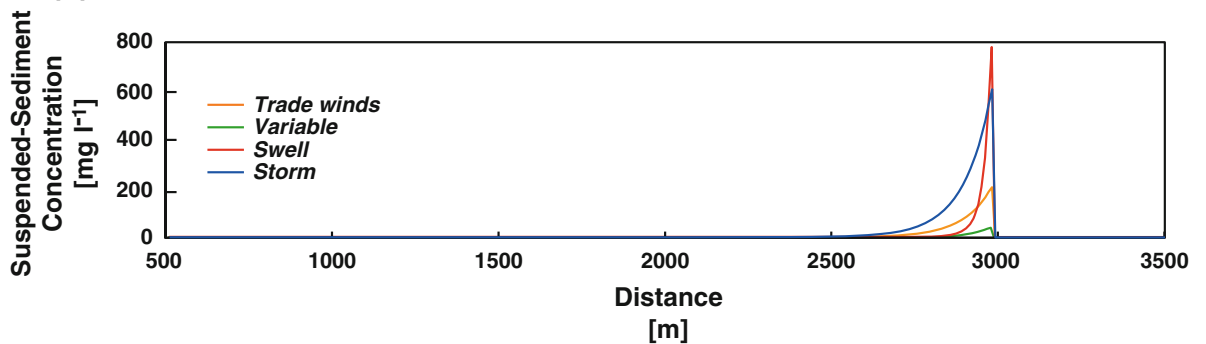

magnitude greater contribution to the annual sediment flux than Swell conditions (Fig. 4c; Table 3). Also of note is the relative contributions of suspended and bed-load flux to the annual total sediment flux (Fig. 4c). While the total sediment flux during Trade Wind conditions is primarily material in suspension, the more energetic Storm conditions result in greater erosion of the "mud belt" deposit and a resulting greater proportion of bed load to the annual total sediment flux.

Effects of sea-level rise on waves and currents

With confidence that the numerical model was successfully reproducing the hydrodynamics and sediment dynamics on the reef flat under present conditions (sea level $=0.00 \mathrm{~m}$ ), mean sea level was then elevated $(+0.10,+0.25,+0.50$, and $+1.00 \mathrm{~m}$ ) to investigate the influence of sea-level rise on waves across the fringing reef. Since the four sets of forcing conditions and 5 different sea-level rise scenarios result in 20 different model runs, for visualization purposes the annual weighted (by frequency of occurrence during the year) mean hydrodynamics and resulting sediment dynamics for the four different forcing conditions are presented for the 5 sea-level rise scenarios in Fig. 5. As sea level increased, the breaking wave height at the reef crest decreased and the location of maximum wave breaking (as evidenced from wave energy dissipation) moved landward (Fig. 5b, c) as more wave energy was able to propagate up onto the reef flat, resulting in greater wave heights on the reef flat. The depth-limited nature of wave height on the 
Fig. 4 Schematization of the forcing data and the resulting modeled net annual sediment flux. a Variations in wave heights for the forcing conditions. b Variations in wave periods for the forcing conditions. $\mathbf{c}$ Variations in wind speeds for the forcing conditions. d Total net suspended-sediment flux. Storm conditions are the dominant contributor to annual sediment flux, contributing just over twice the sediment flux that was modeled during Trade Wind conditions but in only $5 \%$ of the time (a)

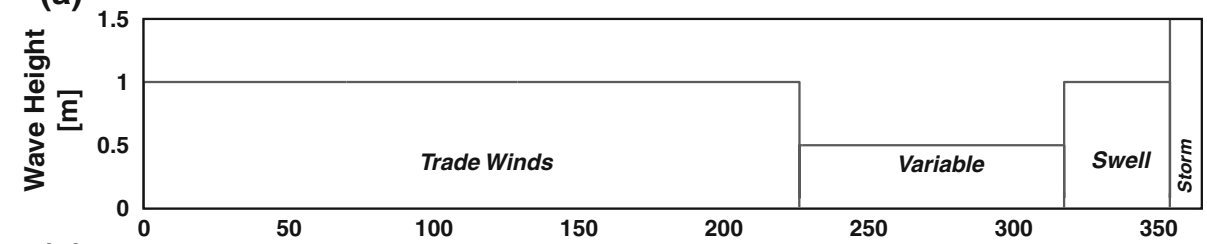

(b)

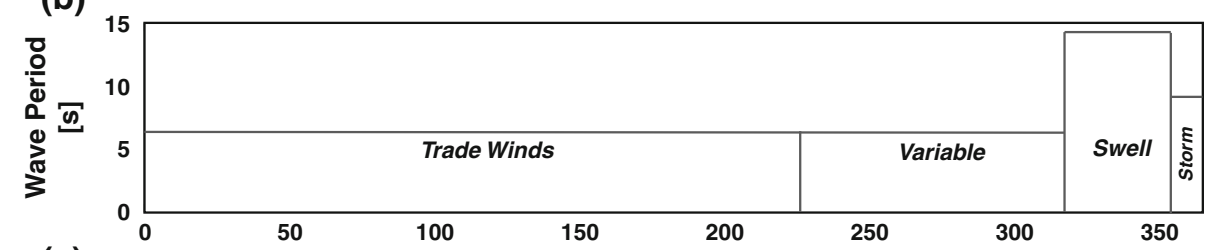

(c)

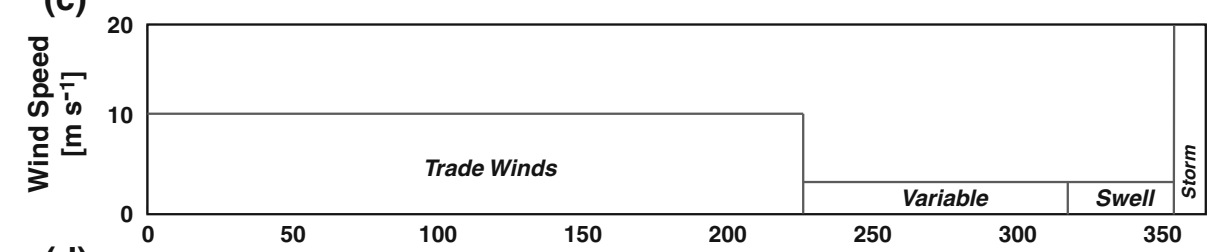

(d)

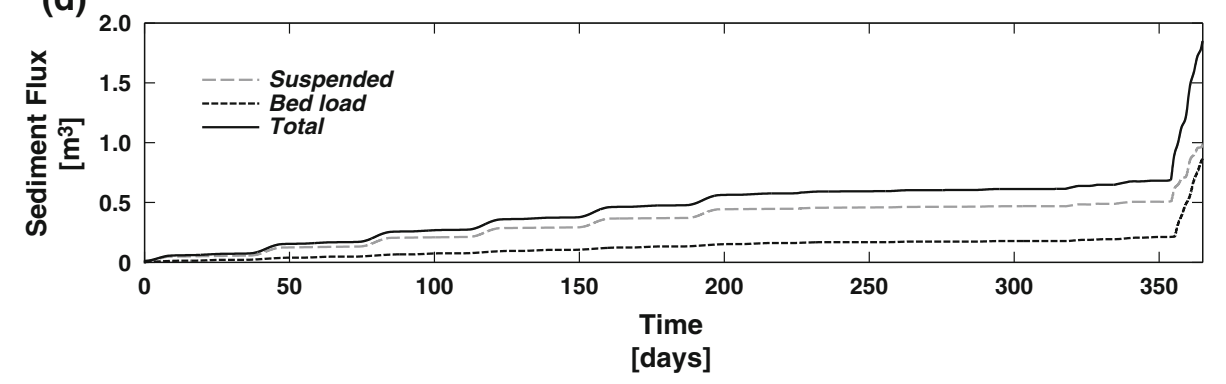

Table 3 Modeled cumulative total annual sediment transport and residence times under present and predicted future sea-level rise scenarios

\begin{tabular}{lllllll}
\hline $\begin{array}{l}\text { Sea level } \\
(\mathrm{m})\end{array}$ & \multicolumn{4}{l}{ Cumulative transport $\left(\mathrm{m}^{3}\right)$} & $\begin{array}{l}\text { Residence } \\
\text { time } \\
\text { (years) }\end{array}$ \\
\cline { 2 - 6 } & $\begin{array}{l}\text { Trade } \\
\text { Wind }\end{array}$ & Variable & Swell & Storm & Total & \\
\hline 0.00 (present) & 0.570 & 0.031 & 0.073 & 1.146 & 1.820 & 10.1 \\
+0.10 & 1.037 & 0.056 & 0.105 & 1.315 & 2.513 & 7.3 \\
+0.25 & 1.942 & 0.111 & 0.141 & 1.454 & 3.647 & 5.0 \\
+0.50 & 3.608 & 0.207 & 0.132 & 2.751 & 6.697 & 2.7 \\
+1.00 & 1.047 & 0.311 & 0.749 & 24.478 & 26.585 & 0.7 \\
\hline
\end{tabular}

reef flat is evident not only in the landward decrease in wave height and energy dissipation due to wave breaking, but also how both of these parameters increase with increasing sea level. As sea level increased, the propagation of larger waves over the reef crest onto the reef flat and in situ growth of wind-waves on the reef flat resulted in elevated peak-bed wave-induced shear stresses (Fig. 5d), especially close to shore in the shallows where the "mud belt" contains a significant proportion of terrestrial material. While increased sea level resulted in increased wave heights, dissipation, and peak-bed shear stresses on the reef flat, the maximum radiation stress-induced setup on the reef flat due to wave breaking decreased and elevated setup extended farther offshore toward the reef crest (Fig. 6b), possibly due to an increase in flow depth over the reef crest and reef flat relative to the hydrodynamic roughness imparted by the corals and ridge-and-runnel structure. At a sea level $+1.00 \mathrm{~m}$ (almost doubling water depth over much of the reef flat), however, run-up onto the coastal plain extended to $+0.30 \mathrm{~m}$ above the oceanic water level $(+1.30 \mathrm{~m}$ total $)$.

Effects of sea-level rise on sediment dynamics

Similar to the study of hydrodynamics, the effect of sea-level rise on sediment-transport rates was investigated by elevating mean sea level $(+0.10 \mathrm{~m},+0.25 \mathrm{~m},+0.50 \mathrm{~m}$, and $+1.00 \mathrm{~m}$ ). The remainder of the model schematizations and parameter settings were unchanged compared to the base case simulation (sea level $=0.00 \mathrm{~m}$ ). Sediment transport in the sea-level rise scenario model runs was governed by the fine sediment fractions, similar to the present-day (sea level $=0.00 \mathrm{~m}$ ) model runs. Current speeds in the "mud belt" were relatively small 
Fig. 5 Modeled cross-shore variations in wave parameters as a function of water depth. a Morphology of the model domain. b Wave height. c Wave energy dissipation. d Waveinduced peak-bed shear stress. Wave height, energy dissipation, and peak-bed shear stress decrease at the reef crest but increase in the reef flat with increasing water depth. Note the greater cross-shore extent (distance $\sim 3,000-3,350 \mathrm{~m}$ ) of the parameters at a sea-level rise of $1.0 \mathrm{~m}$ due to approximately $350 \mathrm{~m}$ of erosion into the coastal plain deposit by the larger waves and resulting high shear stresses
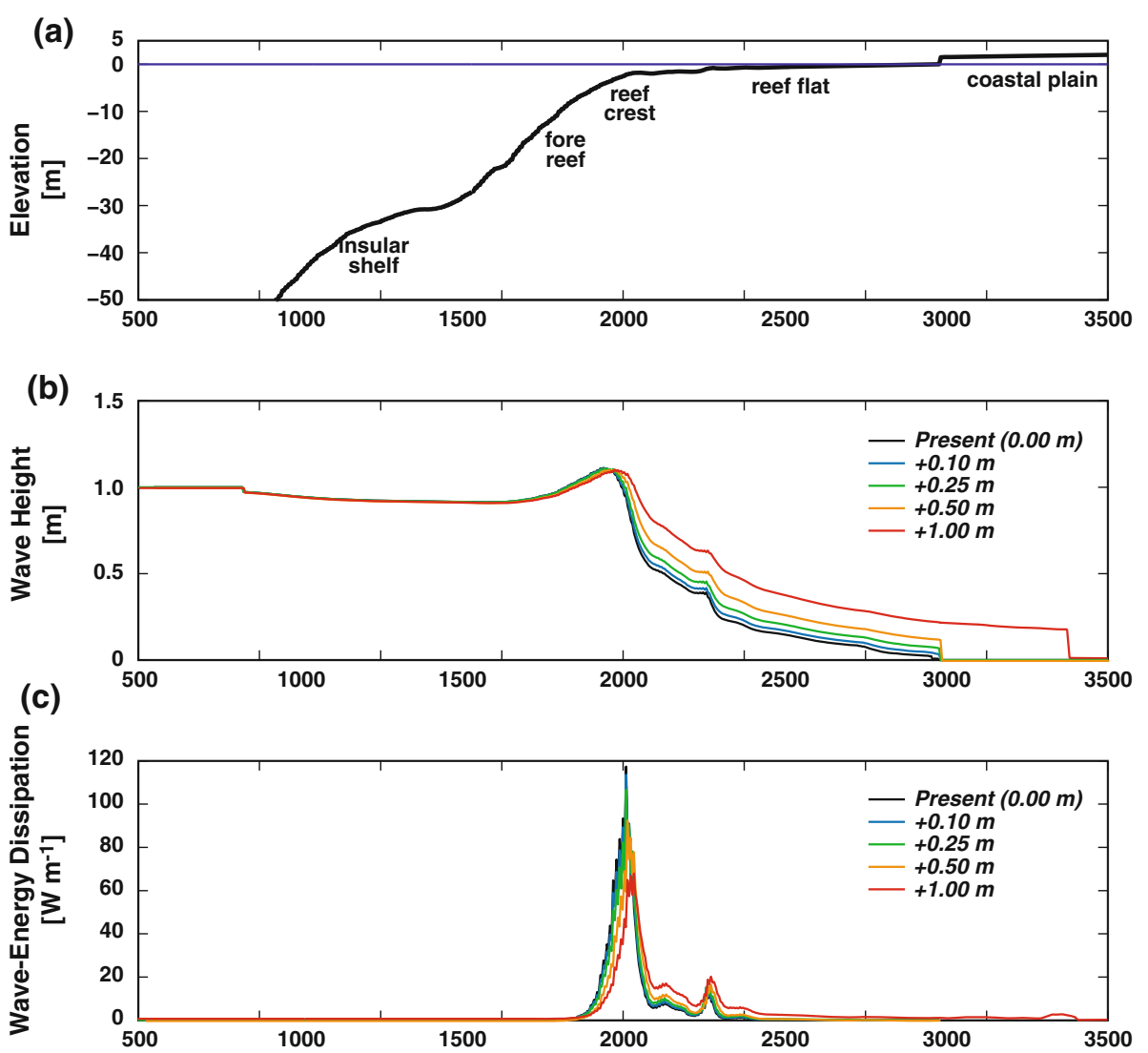

(d)

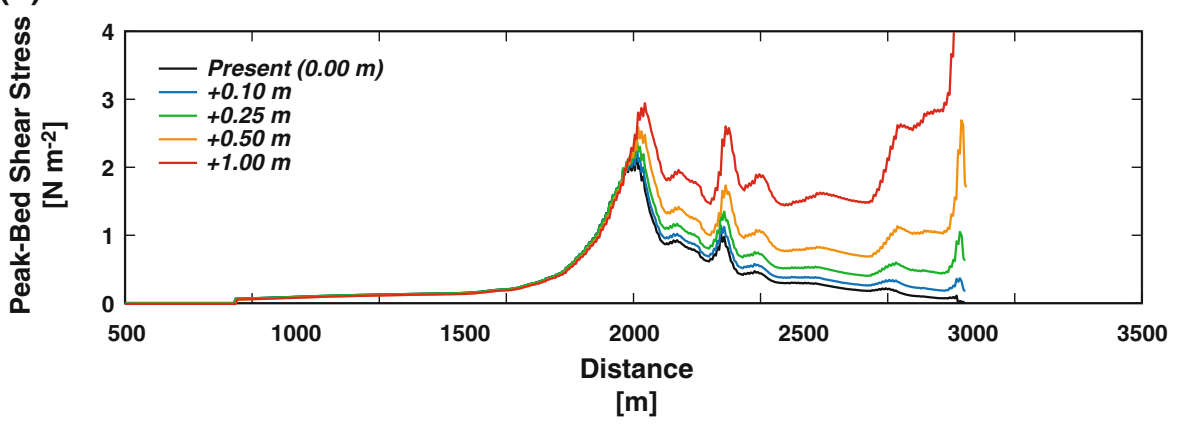

( $\sim 5 \mathrm{~cm} \mathrm{~s}^{-1}$; Fig. 6c) and did not exceed the critical threshold of motion for the larger (sand-sized) grain-size fractions. As sea level was increased, current speeds increased and the relative minima in alongshore current speeds and maxima in cross-shore current speeds at the reef crest due to wave breaking migrated onshore, similar to the maxima in wave height and energy dissipation (Fig. 5).

The higher wave-induced high peak-bed shear stresses (Fig. 5d) and current speeds (Fig. 6c) close to shore resulted in a narrow band of suspended-sediment concentrations and transport along the shoreline (Fig. 6d). Transport rates due to Storm conditions were an order of magnitude larger than the Swell conditions, which were an order higher than Trade Wind conditions. While suspended-sediment concentrations increased in magnitude close to the shoreline and elevated suspended-sediment concentrations extend further across the inner half of the reef flat with increasing sea level between $+0.10 \mathrm{~m}$ and $+0.50 \mathrm{~m}$, there is a distinct change in this pattern when sea level reached $+1.00 \mathrm{~m}$. When sea level was set at $+1.00 \mathrm{~m}$ (almost doubling water depth over much of the reef flat), enough deep-water wave energy was able to propagate onto the reef flat such that larger waves impacted the shoreline, causing significant $(>0.30 \mathrm{~m})$ setup along the shoreline. These waves eroded approximately $350 \mathrm{~m}$ horizontally into the coastal plain deposit, resulting in wave heights (Fig. 5b), water levels (Fig. 6b), currents (Fig. 6c), and suspended-sediment concentrations (Fig. 6d) shoreward of the original shoreline location in the model at a cross-shore distance of 3,000 $\mathrm{m}$. The erosion of the coastal 
Fig. 6 Modeled cross-shore variations in water level, current speeds, and suspended-sediment concentrations as a function of water depth. a Morphology of the model domain. b Total water level, including waveinduced setup. c Alongshore (solid line) and cross-shore (dashed line) current speeds. d Suspended-sediment concentrations. Wave height, energy dissipation, and peakbed shear stress decrease at the reef crest but increase in the reef flat with increasing water depth. Note the greater cross-shore extent (distance $\sim 3,000-3,350 \mathrm{~m}$ ) of the parameters at a sea-level rise of $1.0 \mathrm{~m}$ due to approximately $350 \mathrm{~m}$ of erosion into the coastal plain deposit by the larger waves (Fig. 5)

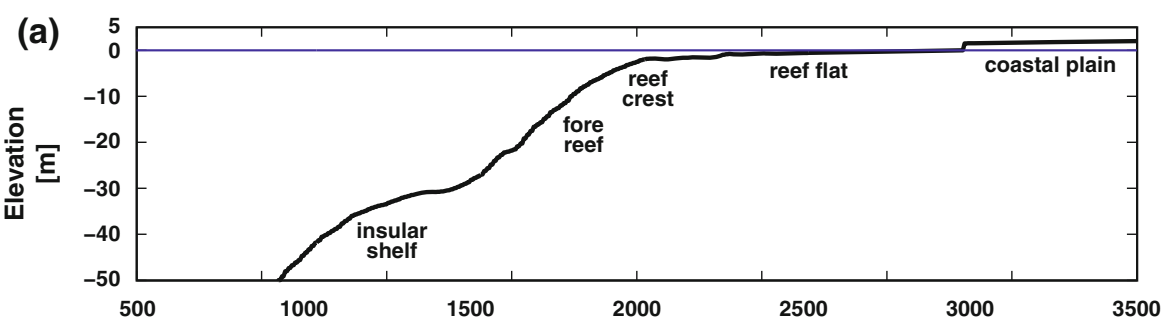

(b)

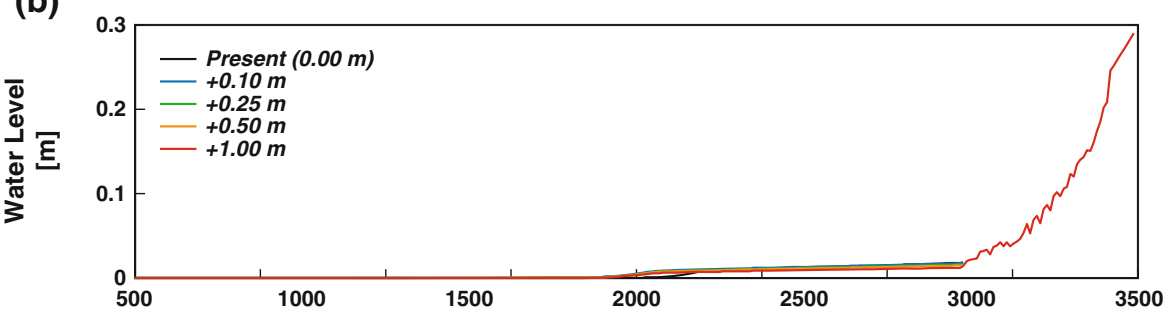

(c)

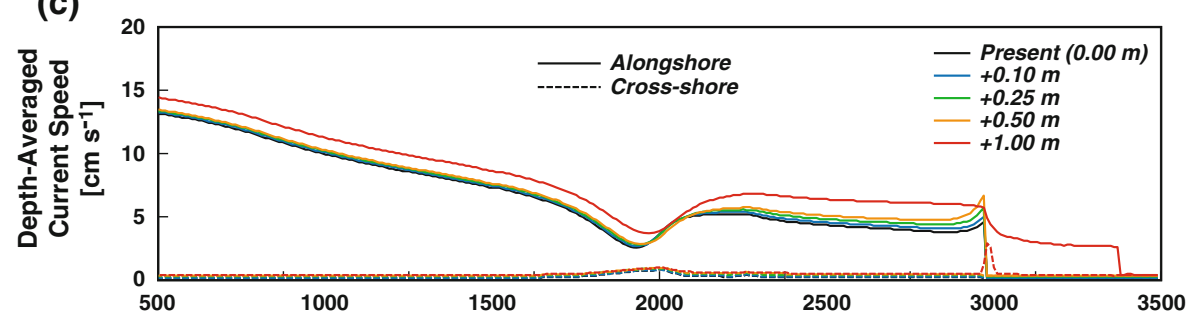

(d)

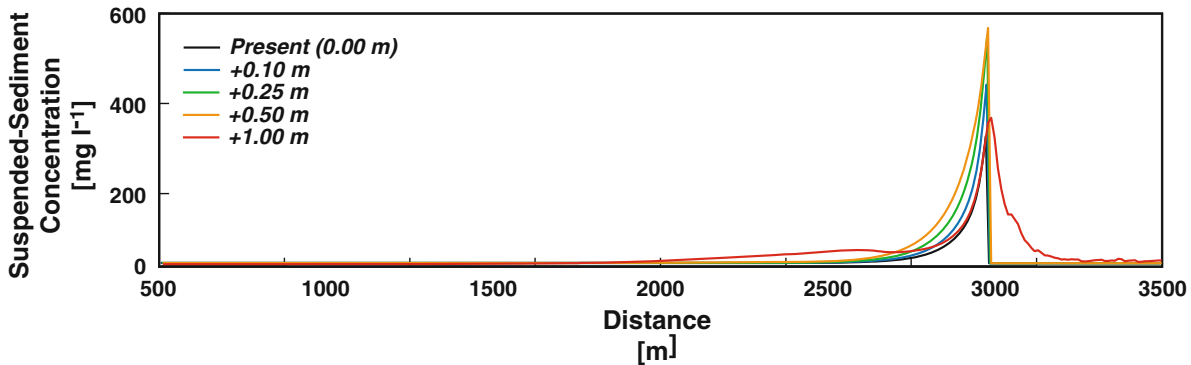

plain deposit resulted in a lower maximum suspendedsediment concentrations but a greater overall volume of material in suspension over the profile (Table 3 ) as the elevated suspended-sediment concentrations extended seaward out to the reef crest (cross-shore distance of $2,000 \mathrm{~m}$ ) and shoreward to the new shoreline (cross-shore distance of $\sim 3,350 \mathrm{~m}$ ). The lower maximum suspendedsediment concentrations at $+1.00 \mathrm{~m}$ of sea-level rise resulted from the erosion of the primarily coarse-grained coastal plain deposit, which provided only $5 \%$ fine-grained material by volume to the reef flat that could easily be resuspended by the waves and currents.

Total sediment-transport rates for each of the simulations are displayed in Fig. 7d-e. There was a statistically significant exponential increase in sediment-transport rates with increasing sea-level rise $\left(r^{2}=0.999\right.$ for $n=5$; $P<0.001)$. As the water level rises over the reef flat, more wave energy propagated to the shoreline, resulting in a greater energy transfer, higher bed shear stresses, greater sediment resuspension, and higher sediment-transport rates. Higher sea-level rise $(0.50-1.00 \mathrm{~m})$, which is on the order of the water depth over the reef flat, resulted in an increase in the dominance of Storm-type conditions due to larger waves breaking closer to the shoreline (Table 3). An estimate of the sediment residence time can be obtained by analyzing the sediment fluxes and available volume (Table 3). For this, the "mud belt" material (fine silt and fine sand) on the reef flat (Fig. 1a, c) was the primary focus, as medium sand was generally not transported in the simulations. Annual cross-shore losses $\left(0.189 \mathrm{~m}^{3}\right.$ year $\left.^{-1}\right)$ in the model were small $(10.4 \%)$ compared to the alongshore transport $\left(1.820 \mathrm{~m}^{3}\right.$ year $\left.{ }^{-1}\right)$. The residence time of sediment in the model can be obtained by analysis of the cumulative transport. At present $(0.00 \mathrm{~m})$ based on a loss of $1.820 \mathrm{~m}^{3}$ year $^{-1}$, it would take 10.1 years for the fine silt-sized terrestrial sediment to be completely removed 
Fig. 7 Schematization of the forcing data and the resulting modeled net annual sediment flux for the five sea-level rise scenarios. a Variations in wave heights for the forcing conditions. b Variations in wave periods for the forcing conditions. c Variations in wind speeds for the forcing conditions. d Total net suspended-sediment flux for the lower magnitudes of sea-level rise. e Total net suspendedsediment flux for the higher magnitudes of sea-level rise. Note that subplots "d" and "e" show some of the same data, but have different $y$-axes to highlight the details in the time series. Higher sea-level rise $(0.50-1.00 \mathrm{~m})$ on the order of the water depth over the reef flat resulted in an increase in the dominance of Storm-type conditions to total sediment flux due to larger waves breaking closer to the shoreline
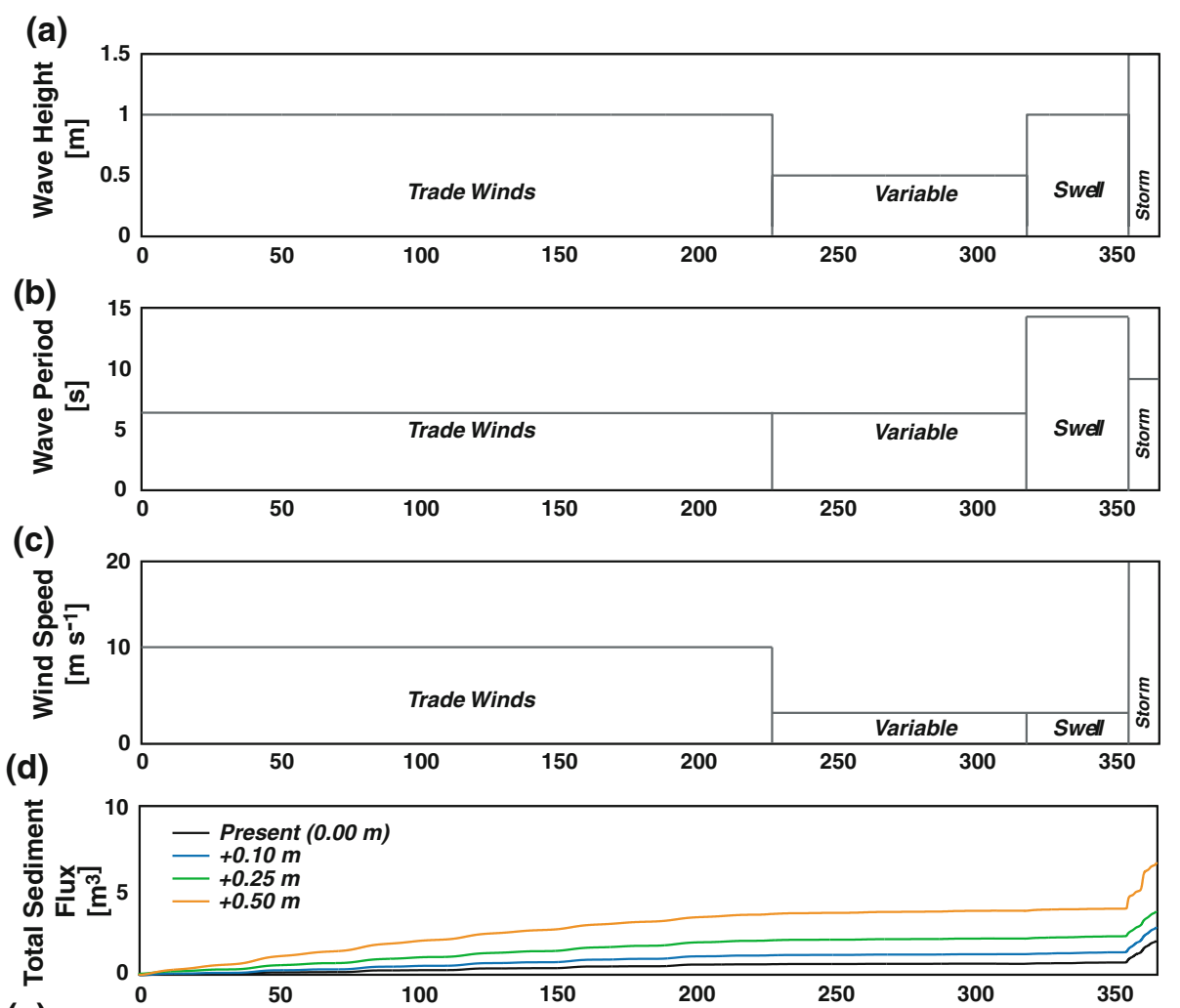

(e)

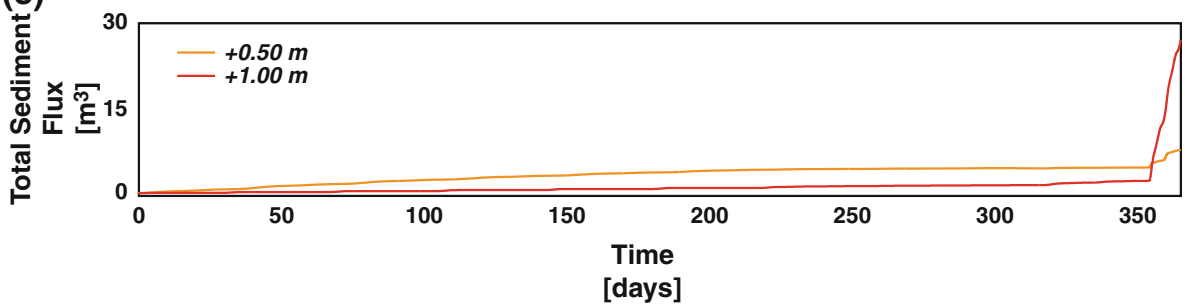

from the "mud belt" in the profile without any additional inputs. Sediment residence time on the reef flat displayed a statistically significant exponential decrease with increasing sea-level rise $\left(r^{2}=0.999\right.$ for $\left.n=5 ; P<0.001\right)$ as the waves and current speeds increase. These calculations are assumed to be a lower limit of the sediment residence time; Presto et al. (2006) predicted a residence time of approximately 30 years based on in situ measurements. For the sand-sized carbonate sediment, the sediment residence time varies around 644 years (rates $\sim 0.044 \mathrm{~m}^{3}$ year $^{-1}$ ) due to the very low frequency of mobilization.

\section{Discussion}

The numerical modeling of hydrodynamics and sediment transport over fringing coral reefs presented here suggest the following changes are expected to occur under future sea-level rise scenarios:
Waves

Greater water depths over a fringing reef would reduce bottom friction and increase water depth relative to the wave height, resulting in larger and more energetic waves that could propagate over the reef crest and reef flat without breaking and larger wind-waves develop in situ on the reef flat, similar to the model results presented by Hearn (1999) and Hearn and Atkinson (2000). These findings are supported by data from Storlazzi et al. (2004), who showed that while wave heights offshore of the reef crest on the fore reef (depth $\sim 10 \mathrm{~m}$ ) are independent of sea level ( $r^{2}=0.003, n=961, P$ not significant $)$, both wave height and wave period on the reef flat (depth $\sim 1 \mathrm{~m}$ ) are significantly correlated with sea level $\left(r^{2}=0.791\right.$ and 0.797 , respectively; both $n=961$ and $P<0.001$ ), suggesting that waves on the reef flat are depth-limited. As sea-level rise increases, the larger waves over the reef and the landward migration of the zone of primary incident wave breaking 
will also modify the zone of high turbulence, primarily moving it shorewards.

\section{Currents}

Increased water depth would result in stronger currents all across the reef due to greater wave-driven flows from larger waves and the reduced height of hydrodynamic roughness relative to water depth that would allow for faster wind-driven currents to develop. The greatest increases in current velocity would be in shallow water on the inner reef flat where the water depth is on order of the hydrodynamic roughness of the seabed. This finding is supported by data from Presto et al. (2006), who showed the current speed at a given location on the reef flat was statistically greater (mean difference $=2 \mathrm{~cm} \mathrm{~s}^{-2}, n=27$, $P<0.05)$ during periods with higher sea level than during periods of lower sea level. This would result in greater water exchange across and lower residence time of water on the reef flat, potentially altering the physical and chemical properties of the water column. The increased mixing and flushing of the reef flat with sea-level rise may help to dilute material delivered to the inner reef flat from the adjacent land, but it might also result in greater transport of terrestrial sediment onto the fore reef. The model results presented here, along with the observations made by Ogston et al. (2004), Storlazzi and Jaffe (2008), and Lowe et al. (2009) and modeled by Gourlay (1996), Hearn (1999), and Hearn and Atkinson (2000), show the effect of sea level on the magnitude of currents, driven both by wind and by wave-breaking, on coral reef flats.

\section{Sediment dynamics}

An increase in wave energy and circulation due to elevated sea level will also affect sediment dynamics across a fringing coral reef. Larger waves resulting from high water levels will generate increased wave-induced stresses, which, in turn, will result in greater resuspension of sediment across the reef for a given grain size or composition (e.g., density) as suggested by Ogston and Field (2010). Statistically greater suspended-sediment concentrations (mean difference $=46 \mathrm{mg} \mathrm{l}^{-1}, n=32, P<0.001$ ) were observed by Presto et al. (2006) during periods with higher sea level; Storlazzi et al. (2004; Fig. 9 therein) showed that suspended-sediment concentrations on both reef flat $\left(r^{2}=0.383\right.$ for $\left.n=961 ; P<0.001\right)$ and fore reef $\left(r^{2}=0.238\right.$ for $\left.n=961 ; P<0.02\right)$ were significantly greater during periods with higher sea level. These observations, combined with their observations showing that greater offshore flow occurred with higher sea level, resulted in a statistically significant greater flux of sediment off the reef flat $\left(r^{2}=0.369\right.$ for $\left.n=961 ; P<0.05\right)$ and over the fore reef $\left(r^{2}=0.576\right.$ for $\left.n=961 ; P<0.001\right)$ with higher sea levels. The greater resuspension and transport would result in higher and longer persistence of turbidity as the increased shear stresses and turbulence would inhibit sediment from settling. The increased resuspension and larger wave-orbital velocities with sealevel rise may also alter patterns of abrasion of corals adjacent to sedimentary deposits such as the sediment-filled "grooves" of spur-and-groove structures. Although alongshore current speeds on the reef flat and over the fore reef are generally much greater $(\sim 2-8$ times $)$ than the cross-shore current speeds (Ogston et al. 2004; Presto et al. 2006), there is strong coupling between offshore flow and high suspended-sediment concentrations on reef flats such that the greatest sediment fluxes generally have an offshore component (Storlazzi et al. 2004). Storlazzi and Jaffe (2008) showed similar reef flat-fore reef coupling off west Maui, especially during periods of large waves and storms when water levels are elevated over the reef flat due to wind- and wave-induced setup.

As pointed out by Graus and Macintyre (1998) and Ogston and Field (2010), the larger waves on the reef flat that would result from sea-level rise will also increase the delivery of energy to the coastline. As these larger, more energetic waves reach the shoreline, which at present is in quasi-equilibrium with the current wave climate, they would exceed the critical shear stresses for resuspension of the beach and coastal plain material, causing coastal erosion and adding additional sedimentary material to the reef flat, similar to the observations by Sheppard et al. (2005). This additional material, resuspended by larger waves and stronger currents, would likely exacerbate turbidity not only on the reef flat but also likely on the fore reef as well (Storlazzi et al. 2004; Storlazzi and Jaffe 2008). Although the stronger currents may reduce the overall residence time of any given sedimentary particle on the reef flat, the increased supply of material by erosion and the increased duration of resuspension for a given set of waves and currents could potentially result in greater exposure of corals to suspended sediment on both reef flat and fore reef.

The one-dimensional modeling by Ogston and Field (2010) on waves and sediment resuspension and the twodimensional coupled hydrodynamics and sediment-transport modeling presented here provide insight into the potential affects of sea-level rise on flow and sediment dynamics over an exposed fringing coral reef based on current observations of forcing conditions (winds and waves). The hydrodynamic and sediment-transport data presented here suggest that while some protected fringing coral reefs many benefit from the additional accommodation space as suggested by Edwards (1995), all will undergo a number of changes in both chemical and biological processes (e.g., Sebens and Johnson 1991; Edwards 
1995; Falter et al. 2004; Storlazzi et al. 2005) due to changes in the hydrodynamics caused by sea-level rise. Many exposed fringing coral reefs may be threatened by additional input and resuspension of terrestrial sediment that will likely negatively affect corals and the ecosystems they support on both reef flat and fore reef, as first postulated by Buddemeier and Smith (1988).

Acknowledgments This work was carried out as part of the US Geological Survey's Coral Reef Project as part of an effort in the United States and its trust territories to better understand the effects of geologic processes on coral reef systems. Andrea Ogston (UW), Joshua Logan, Thomas Reiss, and David Gonzales (USGS) assisted with the fieldwork and instrumentation. We would also like to thank Mark Buckley (USGS), Jeff Hansen (USGS), and the editors at Coral Reefs who contributed numerous excellent suggestions and a timely review of our work. Any use of product, trade, or firm names is for descriptive purposes only and does not imply endorsement by the US Government.

Open Access This article is distributed under the terms of the Creative Commons Attribution Noncommercial License which permits any noncommercial use, distribution, and reproduction in any medium, provided the original author(s) and source are credited.

\section{References}

Booij N, Ris RC, Holthuijsen LH (1999) A third-generation wave model for coastal regions, Part I: model description and validation. J Geophys Res 104:7649-7666

Buddemeier RW, Smith SV (1988) Coral reef growth in an era of rapidly rising sea levels: predictions and suggestions for longterm research. Coral Reefs 7:51-56

DELFT3D User Manual (2010) Delft3D-FLOW: simulation of multidimensional hydrodynamic flows and transport phenomena, including sediment. User Manual, Delft Hydraulics, The Netherlands

Edwards AJ (1995) Impact of climate change on coral reefs, mangroves and tropical seagrass ecosystems. In: Eisma D (ed) Climate change- Impact on coastal habitation. Lewis Publishers, Boca Raton, pp 209-234

Fabricius KE (2005) Effects of terrestrial runoff on the ecology of corals and coral reefs: review and synthesis. Mar Pollut Bull 50:125-146

Falter JL, Atkinson MJ, Merrifield MA (2004) Mass transfer limitation of nutrient uptake by a wave-dominated reef flat community. Limnol Oceanogr 49:1820-1831

Field ME, Cochran SA, Logan JB, Storlazzi CD (2008) The coral reef of south Moloka'i, Hawai'i-Portrait of a sediment-threatened fringing reef. US Geological Survey Scientific Investigation Report 2007-5101 [http://pubs.usgs.gov/sir/2007/5101/sir20075101]

Gourlay MR (1996) Wave set-up on coral reefs, 1: set-up and wavegenerated flow on an idealized two-dimensional horizontal reef. Coast Eng 27:161-193

Graus RR, Macintyre IG (1998) Global warming and the future of Caribbean reefs. Carbonates Evaporites 13:43-47

Grinsted A, Moore JC, Jevrejeva S (2009) Reconstructing sea level from paleo and projected temperatures 200 to 2100 AD. Clim Dyn 34(4):461-472
Hearn C (1999) Wave-breaking hydrodynamics within coral reef systems and the effect of changing sea level. J Geophys Res 104(C12):30007-30019

Hearn C, Atkinson MJ (2000) Effects of sea-level rise on the hydrodynamics of a coral reef lagoon: Kaneohe Bay, Hawaii. In: Noye J (ed) Sea-level changes and their effects. World Scientific Publishing Co Pte Ltd, Singapore, pp 25-48

Holthuijsen LH, Booij N, Ris RC (1993) A spectral wave model for the coastal zone. 2nd International symposium ocean wave measurement and analysis, New Orleans, pp 630-641

Jokiel PL, Brown EK, Friedlander A, Rodgers SK, Smith WR (2001) Hawaii coral reef initiative coral reef assessment and monitoring program (CRAMP) final report 1999-2000. University of Hawaii, Honolulu, p 66

Lesser GR, Roelvink JA, van Kester JATM, Stelling GS (2004) Development and validation of a three-dimensional morphological model. Coast Eng 51(8-9):883-915

Lowe RJ, Falter JL, Bandet MD, Pawlak G, Atkinson MJ, Monismith SG, Koseff JR (2005) Spectral wave dissipation over a barrier reef. J Geophys Res 110(C04001):16

Lowe RJ, Falter JL, Monismith SG, Atkinson MJ (2009) Wave-driven circulation of a coastal reef-lagoon system. J Phys Oceanogr 39(4):869-889

Marszalek DS (1981) Impact of dredging on a subtropical reef community: Southeastern Florida, USA. In: Proceedings 4th international coral reef symposium, vol 1, pp 147-153

Merrifield MA, Merrifield ST, Mitchum GT (2009) An anomalous recent acceleration of global sea-level rise. J Clim 22:5772-5781

Moberly RM, Chamberlain T (1964) Hawaiian beach systems. Hawaii Institute of Geophysics Report HIG 64-2. University of Hawaii, Honolulu, p 177

Montaggioni LF (2005) History of Indo-Pacific coral reef systems since the last glaciation: development patterns and controlling factors. Earth Sci Rev 71(1-2):1-75

Nicholls RJ, Cazenave A (2010) Sea-level rise and its impact on coastal zones. Science 328:1517-1520

Ogston AS, Field ME (2010) Predictions of turbidity due to enhanced sediment resuspension resulting from sea-level rise on a fringing coral reef: evidence from Molokai, HI. J Coast Res 26(6):10271037

Ogston AS, Storlazzi CD, Field ME, Presto MK (2004) Currents and suspended sediment transport on a shallow reef flat: southcentral Molokai, Hawaii. Coral Reefs 23:559-569

Phillip E, Fabricius KE (2003) Photophysiological stress in scleractinian corals in response to short-term sedimentation. J Exp Mar Biol Ecol 287:57-78

Piniak GA, Storlazzi CD (2008) Diurnal variability in turbidity and coral fluorescence on a fringing reef flat: southern Molokai, Hawaii. Estuar Coast Shelf Sci 77(1):56-64

Presto MK, Ogston AO, Storlazzi CD, Field ME (2006) Temporal and spatial variability in the flow and dispersal of suspendedsediment on a fringing reef flat, Molokai, Hawaii. Estuar Coast Shelf Sci 67:67-81

Riegl BM, Dodge RE (2008) Coral reefs of the USA. Springer, Dania

Ris RC, Booij N, Holthuijsen LH (1999) A third-generation wave model for coastal regions, Part II: verification. J Geophys Res 104(4):7649-7666

Rogers CS (1990) Responses of coral reefs and reef organisms to sedimentation. Mar Ecol Prog Ser 62:185-202

Sebens KP, Johnson AS (1991) Effects of water movement on prey capture and distribution of reef corals. Hydrobiologia 216-217:247-248

Sheppard CRC, Dixon DJ, Gourlay M, Sheppard A, Payet R (2005) Coral mortality increases wave energy reaching shores protected by reef flats: examples from the Seychelles. Estuar Coast Shelf Sci 64:223-234 
Spalding MD, Ravilious C, Green EP (2001) World atlas of coral reefs. University of California Press, Berkeley

Storlazzi CD, Jaffe BE (2008) The relative contribution of processes driving variability in flow, shear, and turbidity over a fringing coral reef: West Maui, Hawaii. Estuar Coast Shelf Sci 77(4): $549-564$

Storlazzi CD, Logan JB, Field ME (2003) Quantitative morphology of a fringing reef tract from high-resolution laser bathymetry: southern Molokai, Hawaii. Geol Soc Am Bull 115(11): $1344-1355$

Storlazzi CD, Ogston AS, Bothner MH, Field ME, Presto MK (2004) Wave- and tidally-driven flow and sediment flux across a fringing coral reef: south-central Molokai, Hawaii. Cont Shelf Res 24(12):1397-1419

Storlazzi CD, Brown E, Field ME, Rogers K, Jokiel PL (2005) A model for wave control on coral breakage and species distribution in the Hawaiian Islands. Coral Reefs 24:43-55

Van Rijn LC (1993) Transport of fine sands by currents and waves. J Waterw Port Coast Ocean Eng 119(2):123-143
Van Rijn LC (2007a) Unified view of sediment transport by currents and waves. I: Initiation of motion, bed roughness, and bed-load transport. J Hydraul Eng 133(6):649-667

Van Rijn LC (2007b) Unified view of sediment transport by currents and waves. II: Suspended transport. J Hydraul Eng 133(6):668 689

Van Rijn LC (2007c) Unified view of sediment transport by currents and waves. III: Graded beds. J Hydraul Eng 133(7):761-775

Walstra DJ, Van Rijn LC (2003) Modeling of sand transport in Delft3D. Report Z3624. WL/Delft Hydraulics, Delft

Walstra DJ, Roelvink JA, Groeneweg J (2000) Calculation of wavedriven currents in a 3D mean flow model. In: Proceedings 27th conference on coastal engineering, pp 1050-1063

Wolanski E, Richmond RH, Davis G, Bonito V (2003) Water and fine sediment dynamics in transient river plumes in a small, reeffringed bay, Guam. Estuar Coast Shelf Sci 56(5-6):1029-1040 